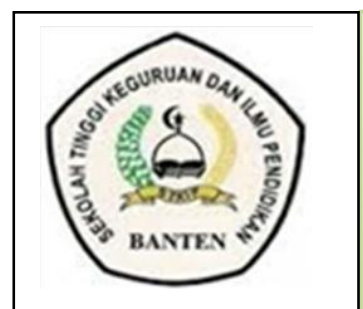

JoEE 1 (1) (2020) : 23-29

JoEE

JURNAL PENDIDIKAN GURU PENDIDIKAN ANAK USIA DINI

http://jurnal.stkipbanten.ac.id/index.php/Joe

\title{
MENINGKATKAN KEMAMPUAN KOGNITIF ANAK TENTANG NAMA-NAMA BINATANG TERNAK DALAM DUA BAHASA (INGGRIS-INDONESIA) MELALUI METODE BERNYANYI
}

\author{
Heni Herlina \\ heniherlina.s.s.mpd@gmail.com \\ Pendidikan Guru Pendidikan Anak Usia Dini \\ Sekolah Tinggi Keguruan dan Ilmu Pendidikan Banten
}

\begin{abstract}
Abstrak
Kognitif yaitu kemampuan anak dalam mengenal, memahami, mengingat, menyebutkan, menyusun dan mengelompokkan serta membedakan benda sesuai bentuk, warna, ukuran, ciri dan fungsinya. Sedangkan metode bernyanyi merupakan metode pembelajaran yang menggunakan syair-syair atau melantunkan kata/ kalimat yang dinyanyikan. Tujuan penelitian ini yaitu: (1) Mengetahui proses pembelajaran dalam peningkatan kemampuan Kognitif anak tentang nama-nama binatang ternak dalam dua bahasa (Inggris-Indonesia) melalui metode bernyanyi. (2) Mengetahui peningkatan kemampuan kognitif anak tentang nama-nama binatang ternak dalam dua bahasa (InggrisIndonesia) melalui metode bernyanyi. Metode penelitian yang digunakan adalah metode kualitatif, dengan jenis penelitian studi literatur (Library Reseach). Hasil dari penelitian yang di dapat adalah: Anak mampu mengingat nama-nama binatang ternak dalam dua bahasa $79 \%$, anak dapat melafalkan/ menyebutkan kembali nama-nama binatang ternak dalam dua bahasa dengan fasih $85 \%$, dan anak mampu membedakan dan mengelompokkan nama-nama binatang ternak sesuai ciri dan fungsinya $87 \%$ signifikan. Kesimpulan dari penelitian menunjukkan bahwa capaian perkembangan kognitif anak tentang nama-nama bintang ternak dengan dua bahasa dengan menerapkan metode bernyanyi dinyatakan berhasil sesuai harapan. Saran untuk penelitian lebih tingkatkan lagi dalam pencarian sumber dari teori-teori yang relevan supaya dapat dijadikan referensi bagi peneliti lainnya.
\end{abstract}

Kata Kunci: Kemampauan Kognitif, Metode Bernyanyi.

\section{PENDAHULUAN}

Berdasarkan Undang- Undang No. 20 Tahun 2003 tentang Sistem Pendidikan Nasional Bab. 1 Pasal. 1 butir 14 dalam Wiyana dan Barnawi (2014: 37) menyatakan bahwa pendidikan anak usia dini adalah suatu upaya pembinaan yang ditujukan kepada anak usia 0-6 tahun yang dilakukan melalui pemberian rangsangan pendidikan untuk membantu pertumbuhan dan perkembangan jasmani dan rohani 
agar anak memiliki kesiapan dalam memasuki pendidikan lebih lanjut.

Kemampuan kognitif diperlukan oleh anak untuk mengembangkan pengetahuan tentang apa yang anak dengar, lihat, raba, rasa ataupun yang ia cium oleh panca indra yang anak miliki. Untuk itu perlu diciptakan media pembelajaran yang inovatif, kreatif, menarik, dan murah. Proses kognitif mencakup kegiatan mental adalah menemukan, memilah, mengelompokan, dan mengingat. Setiap mengingat anak membutuhkan daya ingat yang kuat. Hal itu bisa diperoleh melalui pengalaman serta informasi yang didapat anak dari masa yang lampau. Ingatan merupakan kata lain dari memori, di samping ada yang menggunakan istilah ingatan ada pula yang menggunakan istilah memori. Menurut Kartono dalam Khodijah (2016: 119) memori atau ingatan adalah kemampuan mencamkan, menyimpan, dan mereproduksi kembali hal-hal yang pernah diketahui. Seperti memperoleh informasi dari guru bermacam-macam makanan dan minuman, kemudian anak mampu menyimpan informasi tersebut dalam benaknya dan ketika guru bertanya anak mampu menyebutkan kembali bermacammacam makanan dan minuman. Pada hakikatnya daya ingat sangat berhubungan langsung dengan anak melalui pengalaman, apa yang telah di lihat dan apa yang terjadi di sekeliling anak. Melatih daya ingat anak hendaknya dilakukan sejak usia dini melalui kegiatan pembiasaan yang menyenangkan agar anak memiliki daya ingat yang kuat.

Anak usia TK (4-6 tahun) berada dalam fase perkembangan bahasa secara pasif reseptif dan aktif produkif. Hal ini berarti anak dapat mengungkapkan keinginan dan penolakannya dengan menggunakan bahasa lisan. Bahasa lisan dapat digunakan anak sebagai alat berkomunikasi menurut Jamaris dalam Pratiwi (2018: 4). Pada anak usia 4-6 tahun, anak sudah mampu menguasai 2000 kosakata bahasa menurut Musfiroh dalam skripsi pratiwi (2018: 3) Kemampuan kosakata anak ditunjukkan dengan kemampuan anak bermain dengan katakata, mengetahui arti kata dan secara kontinue anak sudah mampu mengajukan pertanyaan, anak juga sudah mampu menguasai lagu-lagu sederhana, serta anak senang mendengarkan cerita kemudian menceritakannya kembali menurut Soetjiningsih, dalam pratiwi (2018: 4)

Peningkatan penguasaaan kosakata dapat distimulasi dengan berbagai metode pembelajaran, metode tersebut antara lain metode bercerita dan metode bernyanyi. Menurut Sutikno metode pembelajaran adalah cara-cara menyajikan materi pelajaran yang dilakukan oleh pendidik agar terjadi proses pembelajaran pada diri siswa dalam upaya untuk mencapai tujuan. Untuk mengurangi tingkat kesulitan anak dalam mengingat maka peneliti menggunakan metode pembelajaran yang sangat di sukai oleh anak dengan menggunakan metode bernyanyi. Metode bernyanyi merupakan metode pembelajaran yang menggunakan syairsyair atau melantunkan kata/ kalimat yang dinyanyikan. Biasanya syair-syair tersebut disesuaikan dengan materi-materi yang akan diajarkan oleh pendidik. Menurut beberapa ahli, bernyanyi membuat suasana belajar menjadi riang dan bergairah sehingga perkembangan anak dapat di stimulasi secara lebih optimal. Metode pembelajaran bernyanyi dapat membuat siswa lebih semangat dalam belajar apalagi menggunakan gerakan tubuh akan lebih 
memudahkan anak dalam mengingat kosa kata, bahasa yang di sampaikan

Tidak mudah menerapkam metode belajar dengan bernyanyi, banyak hal yang harus kita siapkan secara matang, baik pemilihan lagu, nada, kosa kata yang tepat, irama dan masih banyak lagi. Bernyanyi merupakan hal yang biasa di lakukan anak pada saat kondisi anak tidak bahagiapun bisa dilakukan dan anak bisa terbawa bahagia dengan nyanyian. Disini peneliti menerapkan metode nyanyian dengan bahasa asing yang dimana anak-anak supaya mampu untuk mengikuti kembali pelafalan kata yang di contohkan, mengerti dan memahami kata yang di berikan oleh pendidik, ini merupakan tingkat kesulitan bagi anak dan sebuah tantangan bagi pendidik dalam pembelajaran, namun tidak menjadi kendala bagi peneliti untuk menerapkan metode ini walau dalam bahasa asing, dengan anak bahagia pembelajaran pun akan sangat mudah di terima oleh anak. Maka dari itu peneliti menerapkan metode pembelajaran melalui bernyanyi.

Nyanyian disini sifatnya ialah untuk membantu anak dalam memahami materi dan bisa menghafal sebuah kosa kata yang akan dipraktekkan langsung dalam berkomunikasi disekolah atau diluar sekolah. Kosakata adalah salah satu aspek yang berkaitan dengan perkembangan bahasa anak. Hal ini akan menjadi penilaian dalam pembelajaran sebagaimana disesuaikan dengan indikator (3.6-4.6) pembelajaran tentang kemampuan kognitif yaitu anak mampu menyebutkan dan melafalkan kembali kosakata tentang nama-nama binatang dalam bentuk bahasa inggris dan Indonesia, anak dapat mengingat, membedakan dan mengelompokan namanama binatang ternak berdasarkan bentuk, warna, ciri dan fungsinya dengan baik.

Menurut Yaswinda, 2019: 232. Kemampuan kognitif yaitu kemampuan memecahkan masalah, berpikir logis dan matematis, penerimaan pengetahuan, dan menunjukan keaksaraan. Begitu juga
Chandrawaty, dkk (2020: 26) Mengemukakan dalam bukunya bahwa Kognitif yaitu kemampuan berpikir yang meliputi proses, menangkap, menghubungkan, menilai hingga mempertimbangkan suatu hal.

Berdasarkan permendikbud No. 137 Tahun 2014 dalam Nur dkk (2020: 43) jurnal "Kognitive ability, ecuatic learning, early childrood" mengungkapkan bahwa perkembangan kognitif anak usia dini meliputi: 1) Belajar dan pemecahan masalah, mencakup kemampuan memecahkan masalah sederhana dalam kehidupan sehari-hari dengan cara fleksibel dan diterima sosial serta menerapkan pengetahuan atau pengalaman dalam konteks yang baru. 2) Berpikir logis, mencakup berbagai perbedaan, klasifikasi, pola, berinisiatif, berencana dan mengenal sebab- akibat. Dan 3) Berpikir simbolik, mencakup kemampuan mengenal, menyebutkan dan menggunakan konsep bilangan, mengenal huruf serta mampu mempresentasikan berbagai benda dan imajinasinya dalam bentuk gambar.

Kemampuan kognitif banyak indikatornya yaitu mulai dari kecerdasan berbahasa, membedakan dan mengelompokkan, mengingat, menyebutkan kembali informasi yang ada disekitarnya, dan banyak lagi jenisnya. Beberapa ahli Psikologi yang berkecimpung dalam bidang pendidikan mendefinisikan intelektual atau kognitif dengan berbagai peristilahan. Kognitif adalah kemampuan untuk berfikir secara abstrak. Kognitif adalah kemampuan menyesuaikan diri dengan lingkungan. Kognitif adalah teknik untuk memproses informasi yang disediakan oleh indera intelektual di tambah dengan pengetahuan.

Menurut Madyawati, (2016: 23) dalam bukunya menjelaskan bahwa Kecerdasan linguistik merupakan kecerdasan dalam menggunakan kata secara efektif baik secara lisan maupun tulisan. Kecerdasan ini memiliki empat keterampilan yaitu: menyimak, membaca, menulis dan berbicara. Kiat-kiat 
mengembangkan kecerdasan linguistik pada anak sejak usia dini mencakup: a. Memperkenalkan dan memperdengarkan lagu anak-anak, b. Bermain peran, c. Berdiskusi tentang berbagai hal yang ada di sekitar anak, d. Membacakan cerita atau mendongeng sesuai situasi dan kondisi, e. Mengajak anak berbicara sejak bayi, f. Permainan tebak kata, g. Memperkaya kosakata, h. Membuat pantun dan puisi sederhana. Begitupun menurut Gagne dalam khafifah (2020: 3) menjelaskan "Kognitif adalah proses yang terjadi secara internal di dalam pusat susunan syaraf pada waktu manusia sedang berpikir"

Bahasa memungkinkan anak untuk menerjemahkan pengalaman kedalam simbol-simbol yang dapat digunakan untuk berkomunikasi dan berpikir. Bahasa erat sekali kaitannya dengan perkembnagan kognitif. Bahasa merupakan alat untuk mengekspresikan ide dan bertanya, dan bahasa juga menghasilkan konsep dan kategorikategori untuk berpikir (Susanto, 2011: 73). merupakan suatu proses memahami dan melihat hubungan. Proses ini tidak mungkin dapat berlangsung dengan baik tanpa alat bantu, yaitu bahasa. Bahasa juga merupakan alat berkomunikasi dengan orang lain dan kemudian berlangsung dalam suatu interaksi sosial. (Susanto, 2011: 73-74)

Menurut Fadlillah, (2012: 175) dalam bukunya menjelaskan bahwa metode bernyanyi merupakan metode pembelajaran yang menggunakan syairsyair yang di lagukan. Biasanya syair tersebut disesuaikan dengan materi-materi yang akan di ajarkan oleh pendidik. Bernyanyi membuat suasana belajar menjadi riang dan bergairah sehingga perkembangan anak dapat distimulasi secara lebih optimal.

Berdasarkan teori Bonnie dan John menyatakan bahwa manfaat metode bernyanyi yaitu membantu mencapai kemampuan dalam pengembangan daya pikir, membantu menyalurkan emosi seperti senang atau sedih melalui isi syair lagu/nyanyaian, dan membantu menambah perbendaharaan kata baru melalui syair lagu/ nyanyian. Sedangkan Masykur (2010: 69) menyatakan ada kelebihan dari metode bernyanyi yaitu mampu membantu siswa untuk mengembangkan, memperbanyak kesiapan serta penguasaan keterampilan dalam proses kognitif atau pengenalan siswa.

\section{METODE PENELITIAN}

Metode penelitian yang digunakan yaitu penelitian kualitatif. Menurut Satori dan Komariah (2011: 25) mengemukakan bahwa penelitian kualitatif adalah suatu pendekatan penelitian yang mengungkapkan situasi sosial tertentu dengan mendeskripsikan kenyataan secara benar, dibentuk oleh kata-kata berdasarkan teknik pengumpulan data dan analisis data yang relevan yang diperoleh dari situasi alamiah. Metode penelitian kualitatif adalah penelitian yang bersifat deskriptif dan cenderung menggunakan analisis. Sedangkan jenis penelitian yang digunakan dalam penelitian ini adalah studi literatur (Library Reseach). Studi literatur adalah pencarian terhadap berbagai sumber tertulis, baik berupa buku-buku, arsip, majalah, artikel dan jurnal atau dokumendokumen yang relevan dengan permasalahan yang dikaji. Pentingnya studi litertur karena datanya bersifat tetap, autentik, mudah ditemukan dan dapat dipertanggungjawabkan, karena data literatur tersebut memiliki keabsahan dan telah melalui prosedur penelitian untuk memperoleh data, ini digunakan karena:

1. Data yang diperoleh berupa teoriteori yang mendukung kegiatan penelitian.

2. Data yang diperoleh nanti di gunakan untuk melakukan verifikasi kualitas teori yang ditemukan dari hasil penelitian.

3. Autentik data dari studi literatur dapat dipertanggungjawabkan.

Data yang digunakan berasal dari buku-buku, jurnal dan artikel skripsi, 
review yang berisikan tentang konsep yang di teliti. Penelitian kualitatif tidak hanya sebagai upaya mendeskripsikan data tetapi deskripsi tersebut hasil dari pengumpulan data yang sohih yang di persyaratkan kualitatif yaitu dengan studi literatur dan dengan melakukan triangulasi (komariah, 2011:25).

\section{HASIL PENELITIAN DAN PEMBAHASAN}

Berdasarkan sumber data yang diperoleh dan dilakukan pengamatan lalu dianalisa terhadap sumber yang relevan, maka dapat digambarkan hasil penelitian sebagai berikut:

Penelitian ini dilaksanakan pada tanggal 18 September 2020 sampai 25 Oktober 2020 yang dilakukan dengan meneliti buku-buku, jurnal, artikel dan skripsi. Pengumpulan data dilakukan dengan cara pengamatan dan menganalisa data autentik dari sumber-sumber yang relevan yang dapat di pertanggungjawabkan keabsahannya.

Berdasarkan hasil penelitian yang di dapatkan dari penelitian yang relevan adalah sebagai berikut:

1. Jurnal: Luthfi Nur, dkk. vol. 10 no.1 Universitas Pendidikan Indonesia. (2020). "Kemampuan Kognitif Anak Usia Dini dalam Pembelajaran Akuatik".

a. Anak dapat mengingat nama-nama binatang ternak dengan dua bahasa melalui metode bernyanyi. Contoh: Cow=Sapi, $\quad$ Bird=Burung, Buffalo=Kerbau, dst menujukkan hasil kemampuan kognitif dalam mengingat $81 \%$.

b. Anak dapat menyebutkan kembali nama-nama binatang ternak dalam dua bahasa menunjukkan hasil kemampuan kognitif dalam berbahasa $86 \%$ signifikan.

c. Anak dapat membedakan dan mengelompokkan

nama-nama binatang ternak menunjukkan hasil kognitif 90\%.

2. Skripsi: Ade Fuji Pratiwi, PG-PAUD Universitas Negeri Jambi. (2018). "Peningkatan daya ingat anak usia dini melalui media mind mapping pada kelompok B di TK Islam Al-Muttaqin Kota Jambi".

a. Anak dapat mengingat nama-nama binatang ternak dalam dua bahasa (Inggris- Indonesia) menunjukkan hasil kemampuan kognitif dalam mengingat $80 \%$ signifikan.

b. Anak dapat menyebutkan kembali nama-nama binatang ternak nenunjukkan hasil kemampuan kognitif dalam berbahasa $82 \%$.

c. Anak dapat membedakan dan mengelompokkan nama-nama binatang ternak sesuai ciri dan fungsinya menunjukkan hasil kemampuan dalam membedakan dan mengelompokkan $85 \%$ signifikan.

3. Artikel: Nur Risma Khofifah. Universitas Siliwangi, Tasikmalaya. (2020). "Meningkatkan perkembangan kognitif dengan metode bernyanyi pada anak usia dini”.

a. Anak dapat mengingat nama-nama binatang ternak dalam dua bahasa (Inggris- Indonesia) menunjukkan hasil kemampuan kognitif dalam mengingat $80 \%$ signifikan.

b. Anak dapat menyebutkan kembali nama-nama binatang ternak menunjukkan hasil kemampuan kognitif dalam berbahasa $84 \%$.

c. Anak dapat membedakan dan mengelompokkan nama-nama binatang ternak sesuai ciri dan fungsinya menunjukkan hasil kemampuan kognitif dalam membedakan dan mengelompokkan $87 \%$ signifikan.

Rekapitulasi hasil penelitian kemampuan kognitif anak tentang namanama binatang ternak melalui metode bernyanyi berdasarkan analisis data dari 
sumber-sumber yang relevan di atas adalah sebagai berikut:

$$
\text { Adapun berdasarkan hasil }
$$
penelitian yang relevan diatas, setelah dilakukan pengamatan dan analisis data maka dapat disimpulkan bahwa kemampuan kognitif anak usia dini dalam mengingat nama-nama binatang ternak, menyebutkan/ melafalkan kembali katakata dalam dua bahasa (bahasa Inggrisbahasa Indonesia) dengan fasih dan memahami (membedakan dan mengelompokkan) nama-nama binatang ternak dalam dua bahasa (bahasa Inggrisbahasa Indonesia) melalui metode bernyanyi menunjukan hasil rata-rata diatas $80 \%$ - $85 \%$ signifikan, kata- kata nilai yang dihasilkan yaitu $87 \%$, maka penelitian ini dinyatakan berhasil dan sesuai harapan peneliti.

\section{SIMPULAN DAN SARAN}

\section{A. Simpulan}

Simpulan dari hasil penelitian dan pembahasan pada penelitian meningkatkan kemampuan kognitif anak tentang nama-nama binatang ternak dalam dua bahasa (bahasa inggris-bahasa indonesia) melalui metode bernyanyi adalah sebagai berikut:

1. Terdapat faktor-faktor yang menghambat dan faktor yang mendukung pada penelitian meliputi faktor eksternal dan internal dalam pengamatan dan analisis data yang relevan.

2. Terbukti adanya peningkatan perkembangan kognitif anak melalui metode bernyanyi, meskipun tidak semua anak mengalami peningkatan perkembangan kognitif dengan diterapkannya metode bernyanyi dalam proses pembelajaran tersebut.

3. Ternyata metode bernyanyi dalam proses pembelajaran anak dapat meningkatkan kemampuan kognitif anak tentang nama-nama binatang ternak dalam dua bahasa (inggris-indonesia) dengan hasil rata-rata $87 \%$ signifikan sehingga tujuan penelitian tercapai dengan baik sesuai harapan peneliti.

\section{B. Saran}

Berdasarkan kesimpulan diatas, maka peneliti memberikan beberapa saran sebagai berikut:

1. Bagi Sekolah

Sekolah hendaknya menjaga dan membawa nama baik lembaga dengan senantiasa melengkapi dan menyediakan dan memfasilitasi sarana dan prasarana dalam metode pembelajaran yang jadi bahan ajar di sekolah, baik dilakukan di dalam ruangan maupun diluar ruangan, agar anak didik terbiasa dengan sarana dan prasarana yang ada di tempat mereka belajar, sehingga aspek perkembangan anak dapat tercapai dengan baik, terutama perkembangan kognitif anak.

2. Bagi Guru

Hendaknya para guru lebih meningkatkan kinerja seorang guru dalam menyiapkan bahan dan media pembelajaran serta lebih kreatif dalam menggunakan metode pembelajaran, agar anak lebih semangat dan termotivasi dalam belajar. Jadilah guru yang kreatif dan profesional.

3. Bagi Siswa

Anak-anak lebih di motivasi kembali dalam belajar dan guru harus pandai dalam mengemas metode dan strategi pembelajaran yang dimana anak didik supaya merasa lebih senang dan gembira dalam belajar, sehingga anak tidak merasa jenuh dan membosankan dalam belajar, dan anak yang hiperaktif lebih di arahkan lagi supaya anak tersebut biasa dan bisa mengikuti pembelajaran dengan baik. Dengan metode bernyanyi 
maka anak dengan mudah untuk mengingat, menyebutkan namanama binatang dalam dua bahasa (Inggris-indonesia), dan mengelempokkan nama-nama binatang ternak sesuai bentuk, ciri dan fungsinya, sehingga anak merasa termotivasi dalam meningkatkan kemampuan kognitifnya dengan baik.

4. Bagi Peneliti

Demi kemajuan ke depannya harus lebih kreatif dalam melakukan penelitian dengan menggunakan metode bernyanyi dalam dua bahasa, harus lebih memahami apa yang di cari dalam sumber-sumber penelitian, agar apa yang telah di lakukan dalam penelitian studi literatur dimana tujuan yang diharapkan dapat tercapai dengan baik.

\section{DAFTAR PUSTAKA}

Madyawati, Lilis. (2016) Strategi Pengembangan Bahasa pada Anak. Jakarta: Prenadamedia Group

Yaswinda, (2019) Model Pembelajaran Sains Berbasis Multisensori- Ekologi (PSB MUGI) Bagi Anak Usia Dini. Jawa Barat: Edu Publisher

Susanto, Ahmad (2014) Perkembangan Anak Usia Dini Pengantar dalam Berbagai Aspeknya, Jakarta: Prenadamedia Group

Chandrawaty. (2020) Pendidikan Anak Usia Dini- Perspektif Dosen PAUD Perguruan Tinggi Muhammadiyah, Jakarta: PG Paud Universitas Prof. Dr Hamka

Nur, Luthfi dkk (2020) "Kognitive Ability, Aquatic Learning, Early Childhrood" Pendidikan dan Kebudayaan E-Journal vol.10 no.1 Universitas Pendidikan Indonesia
Fuji Pratiwi, Ade (2018) "Peningkatan daya ingat anak usia dini melalui media mind mapping pada kelompok $B$ di TK Islam Al-Muttaqin Kota Jambi” $\quad$ Skripsi: PG-PAUD Universitas Negeri Jambi.

Khafifah, Nur Risma (2020) "Meningkatkan perkembangan kognitif dengan metode bernyanyi pada anak usia dini" Artikel: Universitas Siliwangi, Tasikmalaya.

Sugiyono (2014) "Metode penelitian kuantitatif, kualitatif dan $R \& D$ ”. Bandung: Alfabeta

Rijali, Ahmad (2018) “ Analisis Data Kualitatif" E-Journal vol. 17 no. 33 h.91-95 UIN Antasari Banjarmasin. 